Nat. Hazards Earth Syst. Sci., 18, 1159-1171, 2018

https://doi.org/10.5194/nhess-18-1159-2018

(C) Author(s) 2018. This work is distributed under

the Creative Commons Attribution 4.0 License.

\title{
Enhancing flood hazard estimation methods on alluvial fans using an integrated hydraulic, geological and geomorphological approach
}

\author{
Zeinab Mollaei, Kamran Davary, Seyed Majid Hasheminia, Alireza Faridhosseini, and Yavar Pourmohamad \\ Water Science \& Engineering Dept., College of Agriculture, Ferdowsi University of Mashhad, \\ P.O. Box: 91775-1163, Mashhad, Iran
}

Correspondence: Seyed Majid Hasheminia (hasheminia@ferdowsi.um.ac.ir)

Received: 21 June 2017 - Discussion started: 18 July 2017

Revised: 27 February 2018 - Accepted: 28 February 2018 - Published: 16 April 2018

\begin{abstract}
Due to the uncertainty concerning the location of flow paths on active alluvial fans, alluvial fan floods could be more dangerous than riverine floods. The United States Federal Emergency Management Agency (FEMA) used a simple stochastic model named FAN for this purpose, which has been practiced for many years. In the last decade, this model has been criticized as a consequence of development of more complex computer models. This study was conducted on three alluvial fans located in northeast and southeast Iran using a combination of the FAN model, the hydraulic portion of the FLO-2D model, and geomorphological information. Initial stages included three steps: (a) identifying the alluvial fans' landforms, (b) determining the active and inactive areas of alluvial fans, and (c) delineating 100-year flood within these selected areas. This information was used as an input in the mentioned three approaches of the (i) FLO-2D model, (ii) geomorphological method, and (iii) FAN model. Thereafter, the results of each model were obtained and geographical information system (GIS) layers were created and overlaid. Afterwards, using a scoring system, the results were evaluated and compared. The goal of this research was to introduce a simple but effective solution to estimate the flood hazards. It was concluded that the integrated method proposed in this study is superior at projecting alluvial fan flood hazards with minimum required input data, simplicity, and affordability, which are considered the primary goals of such comprehensive studies. These advantages are more highlighted in underdeveloped and developing countries, which may well lack detailed data and financially cannot support such costly projects. Furthermore, such a highly cost-effective method could be greatly advantageous and pragmatic for developed countries.
\end{abstract}

\section{Introduction}

Alluvial fan floods are considered to be serious hazards, since the flooding that emerges from the apex of an alluvial fan, moves fiercely downstream while carrying a large amount of substrate load and debris (King and Mifflin, 1991; Coe et al., 2003; Garfi et al., 2007; Merheb et al., 2016). Moreover, alluvial fans are made of larger size sediments which may have some degree of cohesive material that lies on a steep slope. These two characteristics could lead to "avulsion", formation of new channels during flooding events, which causes major flow path displacement (Blair and McPherson, 2009). Estimation of flood hazards on alluvial fans has been a major dispute among hydrologists for many years (Gaume et al., 2009; Bedrossian et al., 2014; Nguyen et al., 2014; Vennari et al., 2016). In fact, due to "avulsion" the characteristics of alluvial fan flooding are more important than other flooding features, which could consequently increase the risk of damage (Calcaterra et al., 2000, 2003; Lancaster et al., 2012; Santangelo et al., 2012). As stated by National Research Council: "the area of deposition on an alluvial fan shifts with time, but the next episode of flooding is more likely to occur where the most recent deposits have been laid down, than where deposits of greatest antiquity occur" (National Research Council, 1996).

Utilizing the alluvial fan characteristics, the United States Federal Emergency Management Agency (FEMA) developed a method to assess the flood risk of alluvial fans. The FEMA guidelines allow for a number of delineation methodologies that include geomorphological method, one- and two-dimensional fixed-bed hydraulic modeling, and composite methods that combine engineering and geological approaches (Federal Emergency Management Agency, 2003). 
The first attempt to address the alluvial fan flood complexities was performed by Dawdy (1979), who developed a probability-based model. The model was based on a mathematical formulation that was developed after a series of catastrophic alluvial fan floods and debris flows in the 1970s. FEMA correctly recognized that riverine floodplain delineation techniques did not adequately depict the flood hazards on active alluvial fans, and adopted Dawdy's equations to better describe the flood risks associated with non-riverine processes such as avulsions, high rates of sediment transport, and net aggregation (Dawdy, 1979). FEMA applied this approach directly in a number of alluvial fan floodplain delineation studies in the 1980s, and thereafter, the FAN model was developed (Federal Emergency Management Agency and Federal Insurance Administration, 1990). The FAN model is a DOS-based software package that uses Dawdy's basic equations as well as a modification proposed by DMA Consulting Engineers (1985) to predict flow depths and velocities on alluvial fans on a regular basis (French et al., 1993).

During the last decade, the FAN model has been profoundly criticized by some researchers (House et al., 1991; Field and Pearthree, 1992; French, 1992; Pearthree et al., 1992; French et al., 1993; Fuller, 1990, 2013) since it does not consider the physical characteristics of alluvial fans. Despite all the criticism raised about this model, it can still be a useful tool to delineate alluvial fan flooding. In addition, it is a simple model for predicting flood risk. According to this model, the areas subjected to alluvial fan flooding are assumed to have an equal width (Federal Emergency Management Agency and Federal Insurance Administration, 1990). This width is referred to as the contour width, since it is measured along a contour. However, the hydraulic models fill the sinks based on topographic maps, and depth and velocity are just computed as a point. Nevertheless, in order to interpret the risk of flood areas, hazard zones are required rather than simply hazard points (Gallien, 2016).

Alluvial fan flows are two-dimensional; therefore, the application of one-dimensional flow hydraulic models on alluvial fans has the following limitations: (i) difficulties and inaccuracies in determining flow direction on floodplains; (ii) lack of flood volumes in determining the flooding boundaries, and (iii) problem with the uncertain nature of flood discharge calculation (Volker et al., 2007; Yunsheng, 2009). Marchi et al. (2010) used an integrated approach to analyze the hydro-geomorphological processes and their interactions with torrent control works and applied it to a large alluvial fan in the southern Carnic Alps (northeastern Italy). Their study encompassed field observations, interpretation of aerial photographs, analysis of historical documents, and numerical modeling of debris flows (Marchi et al., 2010).

In addition, it has been found that geological and geomorphological data have great impact on estimation of avulsion intensities (Fuller, 2012). Studies conducted on 100-year floods in alluvial fans using the mentioned methods empha- size the fact that formulating a framework for the geologicalgeomorphological features of the area can profoundly improve our understanding of their role in flood risk assessment (House, 2005). In another study, integrated geological maps, geomorphological analysis, and a two-dimensional hydrodynamic model (LISFLOOD) were used to assess flood hazards (Pelletier et al., 2005). In another study, a multi-criteria index to assess flood hazard areas in a regional scale was introduced (Kazakis et al., 2015). Accordingly, a flood hazard index (FHI) was proposed and a spatial analysis in geographic information system (GIS) environment was applied for the estimation of its value. Recently, a framework was presented for mapping potential flooding areas integrating GIS, fuzzy logic and clustering techniques, and multi-criteria evaluation methods (Papaioannou et al., 2015). To sum up, geological maps could be a powerful tool for better analyzing avulsion due to incorporating the effects of erosion and sedimentation. In fact, using geomorphological analysis can provide (i) a context for understanding the basic system processes, (ii) understanding the type of processes that have occurred from the past up to present, and (iii) calibration or verification of hydraulic modeling results (Calcaterra et al., 2003; Garfi et al., 2007; Santo et al., 2015).

The goal of this study was to examine the applicability of overlaying three layers of land/ground susceptible to erosion, water erosion potential, and hydraulic flooding zones in alluvial fans with the least needed data. The Ferizy and Ardak alluvial fans in Khorasan Province and the Sarbaz fan in Sistan and Baluchestan Province, which are all located in arid regions in the eastern part of Iran, were considered for this study. In this paper, a new method is introduced and applied for each data layer and the results are discussed.

\section{Methods and materials}

In this study, a simple flowchart was followed to achieve the final flood hazard map, which is illustrated in Fig. 1. The proposed model needs four input data in order to obtain a flood hazard map, which are $Q_{100}$ hydrograph, topographic map, normalized difference vegetation index (NDVI), and field investigations.

Five steps have been followed to achieve this goal:

1. the FAN model was established using the 100-year return period hydrograph and the average slope which was extracted from topographical maps;

2. the FLO-2D model was executed by using the 100-year return period hydrograph and topographical maps;

3. active and inactive areas were distinguished by considering topographical maps, NDVI, and field investigations;

4. thereafter, all the models, results, and field investigations were georeferenced and overlapped in GIS as sep- 


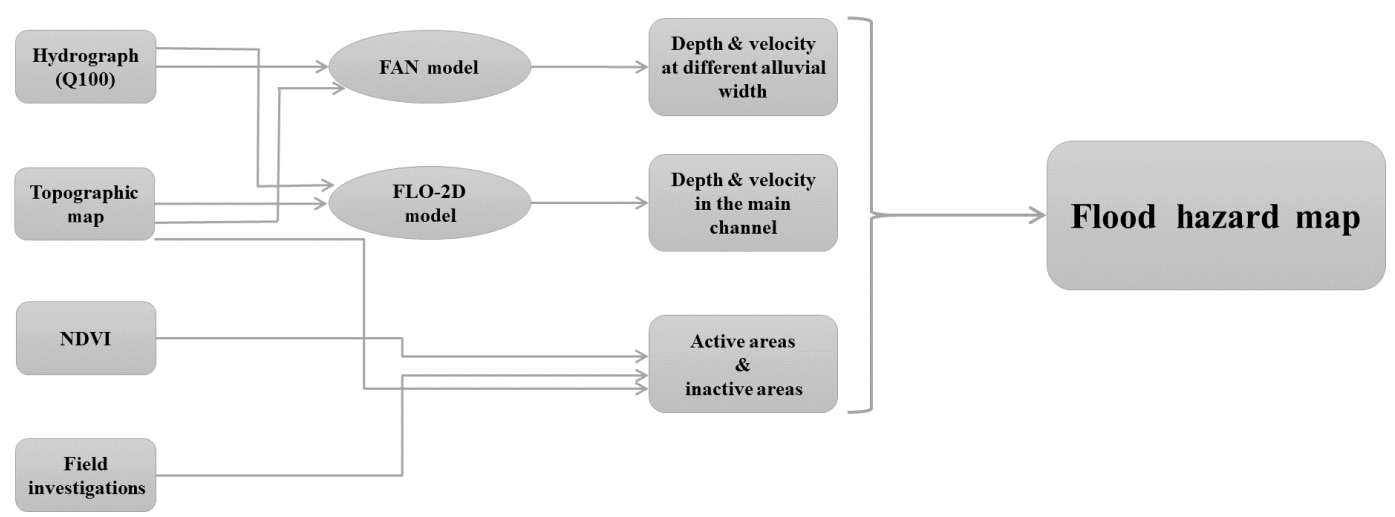

Figure 1. The flow chart proposed for creating the flood hazard map.

arated layers and each layer was appointed a score using a scoring system from 0 to 1.5 ;

5. finally, the score of layers was multiplied and afterwards the pixels with the highest value and pixels with a score of 0 were considered to be the highest and the lowest hazard zones, respectively.

\subsection{Input data}

\subsubsection{Hydrograph $\left(Q_{100}\right)$}

Thirty-five years of hydrometric data were obtained from water authority company for each area. Afterwards, the 100-year return period hydrographs $\left(Q_{100}\right)$ were developed, based on collected data for all three fans in a spreadsheet. These hydrographs were used in the FAN model and FLO-2D as input data. Figure 2a, b, and c illustrates the $Q_{100}$ hydrographs for the Ardak, Ferizy, and Sarbaz fans, respectively.

\subsubsection{Topographic map}

Georeferenced elevation maps were downloaded in TIFF files format from USGS (United States Geological Survey) website for all three fans with a resolution of $50 \mathrm{~m} \times 50 \mathrm{~m}$. Afterwards, using GIS tool, the average slope map was derived from elevation map and used as an input in the FAN model.

Georeferenced elevation maps were used as FLO-2D model input; however, contour maps were the primary input of this model. The process of converting elevation maps to contour maps was performed in the FLO-2D model; therefore, no extra calculations were needed. Figure $3 a, b$, and c show the elevation map for the Ardak, Ferizy, and Sarbaz fans, respectively.

\subsubsection{Normalized difference vegetation index (NDVI)}

To cover all three study areas, two Landsat 8 OLI Images (path/row: 159/35 and 156/42) on 13 May for the Ardak
Table 1. Observation conclusions from field investigations.

\begin{tabular}{lllcc}
\hline & Fan & Location & Latitude & Longitude \\
\hline 1 & Ferizy & apex & 36.54889 & 59.09964 \\
2 & Ferizy & Jam Ab & 36.57275 & 59.10208 \\
3 & Ferizy & industrial area of Chenaran & 36.57275 & 59.10208 \\
4 & Ferizy & farms & 36.60528 & 59.10227 \\
5 & Ferizy & ring road & 36.61469 & 59.11415 \\
6 & Ardak & apex & 36.74175 & 59.39865 \\
7 & Ardak & farms & 36.73803 & 59.39892 \\
8 & Ardak & rural area & 36.73184 & 59.39389 \\
9 & Sarbaz & apex & 26.20120 & 61.73763 \\
10 & Sarbaz & inactive area & 26.18299 & 61.74807 \\
11 & Sarbaz & Suldan village & 26.15361 & 61.78557 \\
\hline
\end{tabular}

and Ferizy fans and 24 May for the Sarbaz fan were downloaded from the USGS website with a spatial resolution of $30 \mathrm{~m} \times 30 \mathrm{~m}$. These two images were clipped to alluvial fan borders.

To calculate NDVI, first the reflectance of bands 4 and 5 (red and infrared) were calculated based on the Landsat 8 Users Handbook (Zanter, 2016) and then the following equation was applied on bands 4 and 5 reflectance (Li et al., 2013).

$\mathrm{NDVI}=\left(\left(\rho_{\mathrm{NIR}}-\rho_{\mathrm{Red}}\right)\right) /\left(\left(\rho_{\mathrm{NIR}}+\rho_{\mathrm{Red}}\right)\right)$,

where $\rho_{\mathrm{NIR}}$ and $\rho_{\text {Red }}$ are reflectance of near-infrared band and reflectance of red band, respectively. The calculated NDVIs for the three fans are illustrated in Fig. 4a-c.

\subsubsection{Field investigations}

Field trips to the Ardak and Ferizy fan (20 May) and to the Sarbaz fan (25 May 2015) were carried out to assess some geomorphological features for delineation of the active and inactive areas. These information included slope, drainage patterns, topographic contour, superficial characteristics, desert pavement, desert varnish, color, and distinctive vegetation (Coe et al., 2003; Garfi et al., 2007; Elkhrachy, 2015; Vennari et al., 2016). This investigation was performed in order 

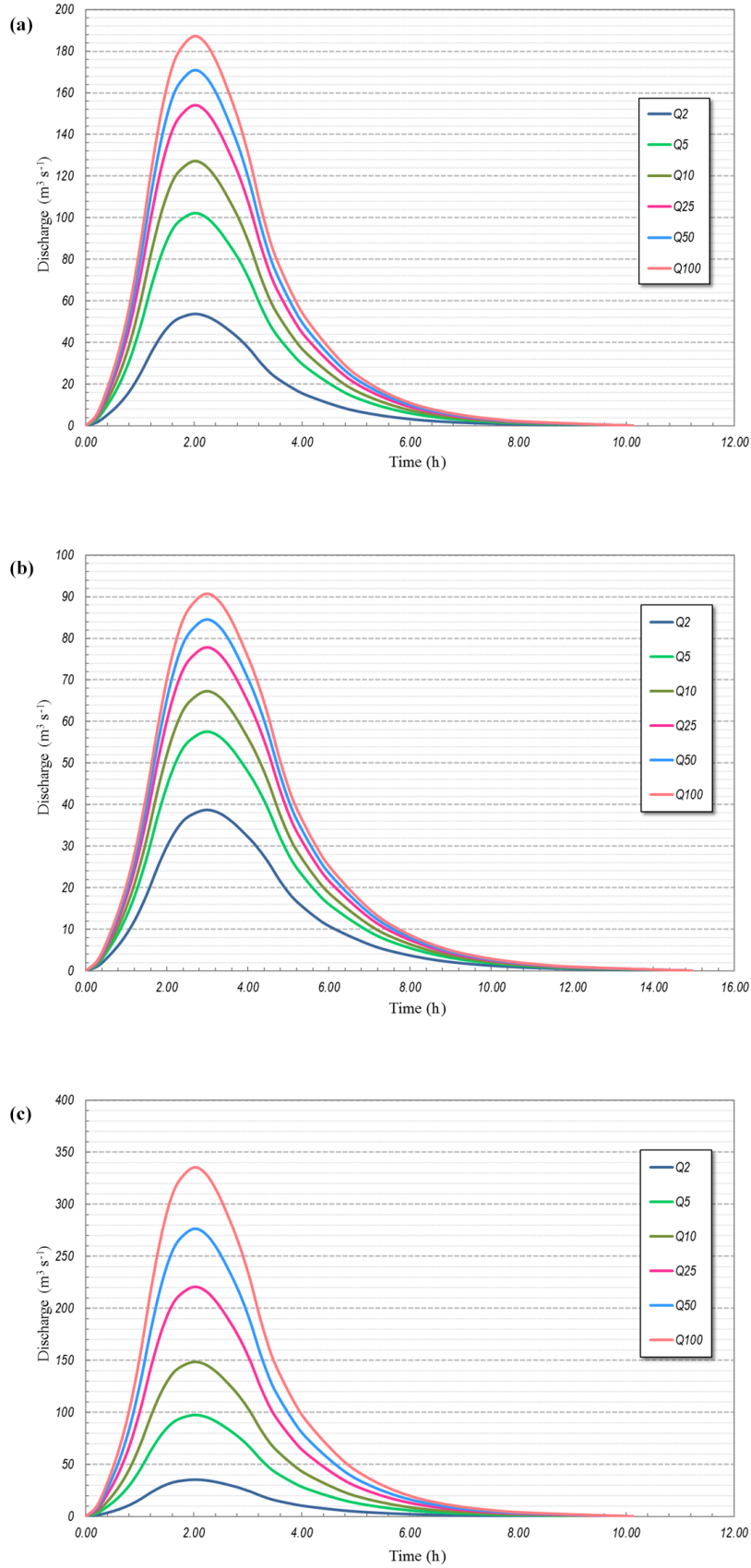

Figure 2. $Q_{100}$ for the (a) Ardak, (b) Ferizy, and (c) Sarbaz fans.

to determine active and inactive areas and validate the satellite images. The observations are presented in Table 1.

Landsat 8 aerial photographs were used to determine active or inactive areas, which were downloaded from the USGS website. The evaluation was done by using the surface color and vegetation detection in photos. A dark surface color indicated an inactive zone, while lighter surfaces represented more active areas (Lohani et al., 2006).
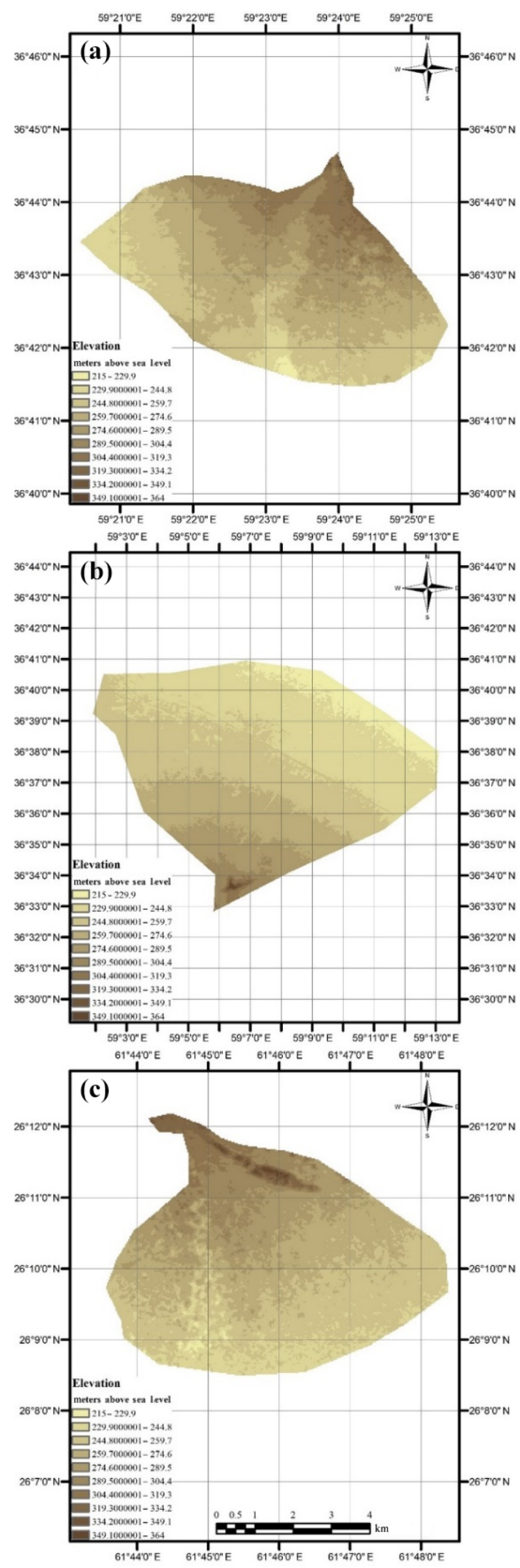

Figure 3. Land elevation from Aster dataset for the (a) Ardak, (b) Ferizy, and (c) Sarbaz fans. 

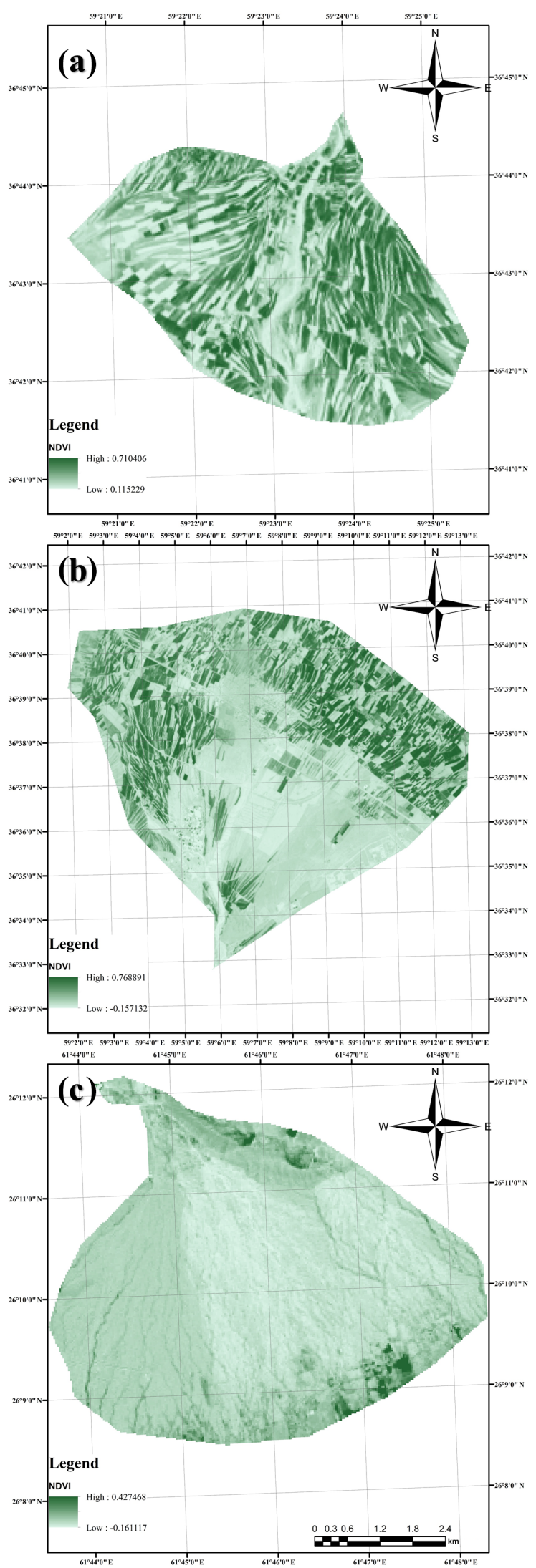

Figure 4. Calculated NDVI for the (a) Ardak, (b) Ferizy, and (c) Sarbaz fans.

\subsection{Models}

\subsubsection{FEMA's FAN model}

As stated before, the FEMA method uses Dawdy's theory to delineate alluvial fan flooding to develop the FAN model (Federal Emergency Management Agency and Federal Insurance Administration, 1990). Based on Dawdy's theory the flood channel occurs randomly in active alluvial fans. Therefore, each point in an active area of a fan has similar chance to become a new channel as other points, so each point has the tendency to flood. Hence, the probability of flood incidence in this model can be determined as follows (for more information see FAN model manual):

$P(H=1)=\int_{q_{0}}^{\infty} P_{H \mid Q}(1, q) f_{Q}(q) d q$

$H=\left\{\begin{array}{ll}1 & \text { if the location is inundated } \\ 0 & \text { if the location is not inundated }\end{array}\right.$,

where $Q$ is a random variable denoting the magnitude of the flood, $P_{H \mid Q}(1, q)$ is the probability that a location will be inundated, given that a flood of magnitude $q$ is occurring, and $f_{Q}$ is probability density function (PDF) defining the likelihood that a flood of a magnitude between $q$ and $q+d q$ will occur in any given year.

Based on the assumptions of this model all areas of the alluvial fan could be subjected to flooding and there is a fixed relation between flooding depth and discharge (Federal Emergency Management Agency and Federal Insurance Administration, 1990; Federal Emergency Management Agency, 2003). The flood hazard areas on an alluvial fan are identified as AO zones. An AO zone is defined as the flood insurance rate zone that corresponds to the areas of 100-year shallow flooding (usually sheet flow on sloping terrains), where average depths are between 0.3048 and $0.9144 \mathrm{~m}$. The flood hazard area on an alluvial fan is subdivided into separate $\mathrm{AO}$ zones with similar flooding depths (water depth plus velocity head) and velocities (Zhao and Mays, 1996). Figure 5 is an example of $\mathrm{AO}$ zones according to depth and velocity (Federal Emergency Management Agency and Federal Insurance Administration, 1990).

\subsubsection{FLO-2D model}

FLO-2D is a two-dimensional flood routing hydraulic model which is commonly used by civil environmental engineers to delineate flood hazard maps, implement floodplain zoning, and design flood mitigation schemes (Yunsheng, 2009; Mollaei et al., 2016a). In this model the full dynamic wave equation and central finite-difference routing scheme with eight potential flow directions are used to predict the progression of a flood hydrograph over a system of square grid elements (O'Brien et al., 1993). This model is characterized by some substantial advantages (Fuller, 2010): 


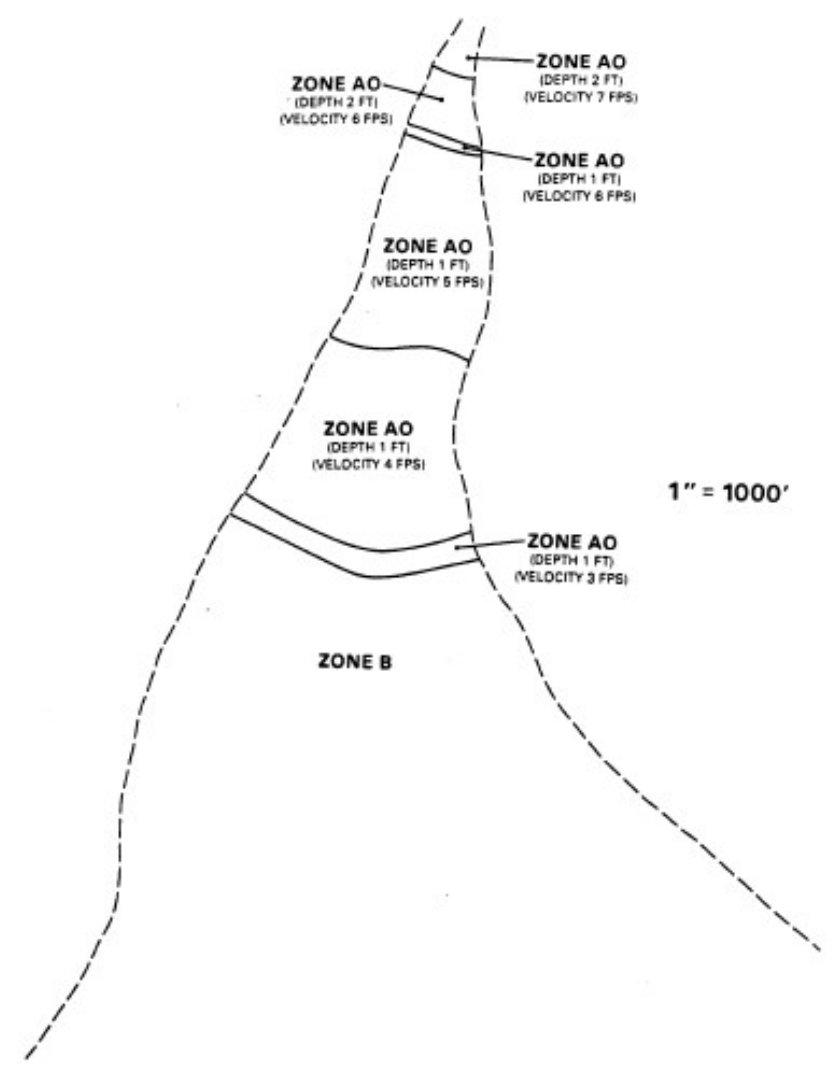

Figure 5. Examples of AO zones according to depth and velocity in the FAN model (Federal Emergency Management Agency and Federal Insurance Administration, 1990).

i. runoff can flow anywhere along the dominant boundary, not only at the concentration point;

ii. peak discharge can be generated anywhere within the model domain, not just at the concentration route;

iii. in adjacent alluvial fans, the flow can be easily modeled along unconfined boundaries;

iv. watershed parameters are distributed over each small grid cell rather than being lumped over large sub-basins;

v. there is no need to estimate hydrological routing parameters or average the hydraulic routing cross sections, since routed hydrographs are inherent in the model.

The FLO-2D-based model revealed that floods are not transferred via a single channel at fan evaluation sites and flow path locations could be predicted if floods have minimal sediment transport and a relatively constant topography (Fuller, 2010).

This model is sensitive to grid size and topographical data. To increase the accuracy of the model, small size grids and topographical data with minimum distance between contour lines should be used (Fuller, 2012). In this study, the FLO2D model was used only as a hydraulic model; therefore, a precision of $30 \mathrm{~m}$ by $30 \mathrm{~m}$ grid size and $50 \mathrm{~m}$ by $50 \mathrm{~m}$ topographical data were chosen, while the values of Manning coefficients were determined according to the land use information.

\subsubsection{Geomorphological analysis}

Geomorphological features for delineation of active and inactive areas include slope, drainage patterns, topographic maps, superficial characteristics, desert pavement and varnish, color, and distinctive vegetation (Field and Pearthree, 1992; Coe et al., 2003; House, 2005; Garfi et al., 2007; Lancaster et al., 2012; Santangelo et al., 2012; Fuller, 2013).

For this purpose, in addition to utilizing aerial photographs, a field trip was performed to inspect and distinguish the active and inactive areas of the three alluvial fans as suggested by FEMA (Federal Emergency Management Agency, 2003). This was performed by using the surface color and vegetation detected in photos. A dark surface color is an indication of an inactive zone, while lighter surfaces represent areas that are more active. Figure 6a, b, and c illustrates the aerial images of the Ardak, Ferizy, and Sarbaz alluvial fans, respectively. The density of natural vegetation provides useful insights into inactiveness of an area. For instance, areas with annual plants were considered to be active, while areas with perennial plants were considered to be inactive. In addition, observation of human activities or weathering footprints (desert pavement, desert varnish, and limestone cracks or grooves) can provide useful information about the extension of inactiveness of an area (Garfi et al., 2007). Finally, distributary, braided, and branching drainage patterns are characteristics of active areas, whereas tributary patterns are an indicator of inactive areas. For this purpose, the 2015 Aerial images of the three alluvial fans were downloaded from the USGS website.

\subsection{Overlaying the GIS layers}

Hazardous zones in the FLO-2D and FAN models and geomorphological characteristics studies were defined based on their depths, velocities, and areas of activeness. These criteria are presented in Table 2. Note that the FLO-2D model classified inundated areas as hazardous zones based on criteria presented in Table 2. This model assumes the rest of the areas as being out of the flooding hazard zones.

\subsection{The study area}

This study was performed on three separated alluvial fans (Ferizy, Ardak, and Sarbaz) in Iran. The Ferizy fan is located on the northern piedmont slopes of the Binalud Mountains in Khorasan Province. Currently, it is being developed by agricultural, residential, and industrial projects. Chenaran industrial area is situated right below the hydrographic apex (Mollaei et al., 2016b). 

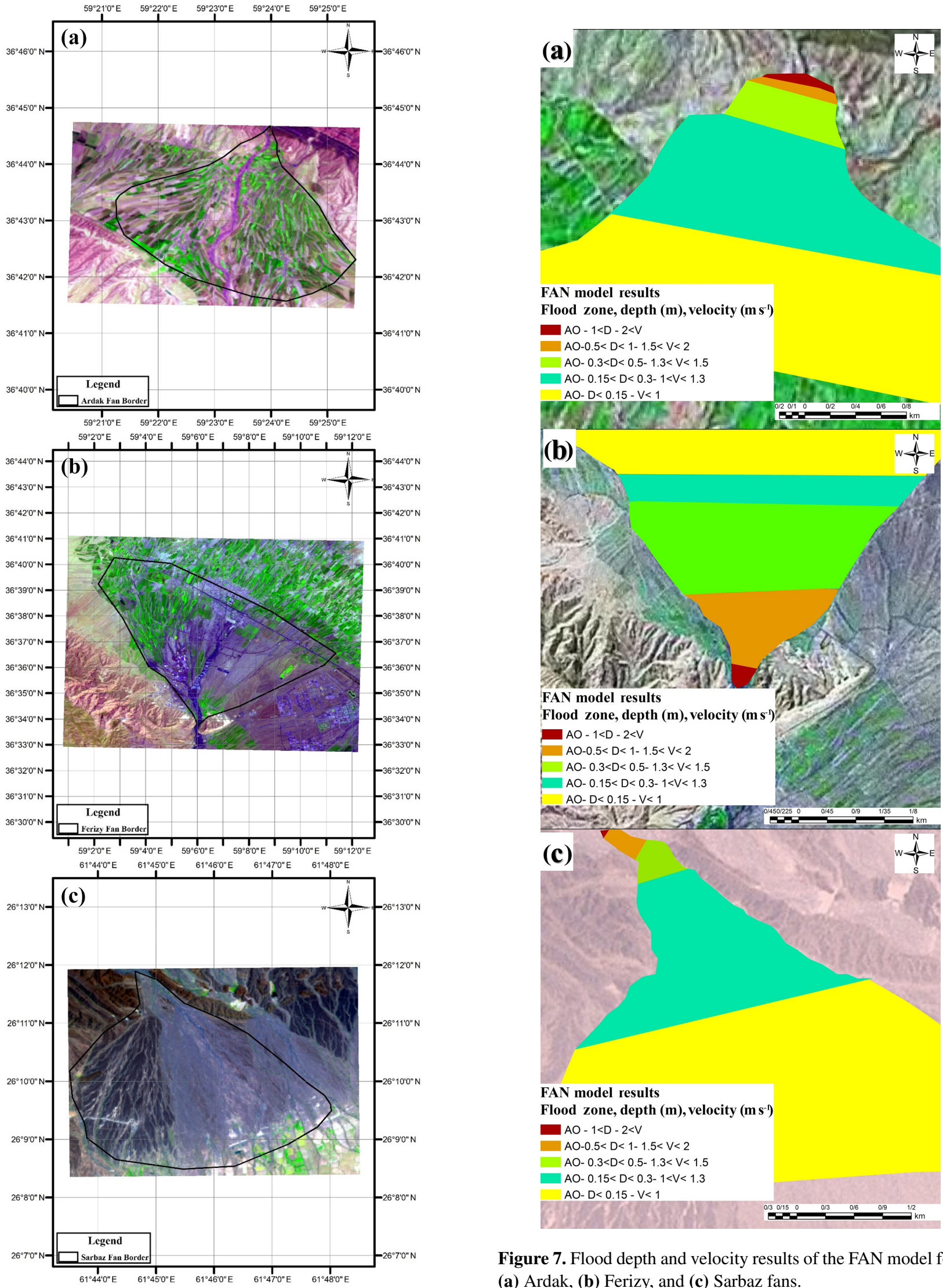

FAN model results

Flood zone, depth (m), velocity ( $\left.\mathrm{m} \mathrm{s}^{-1}\right)$

aO $-1<\mathrm{D}-2<\mathrm{V}$

$A O-0.5<D<1-1.5<V<2$

AO- $0.3<D<0.5-1.3<V<1.5$

AO- $0.15<D<0.3-1<V<1.3$

$A O-D<0.15-V<1<1$
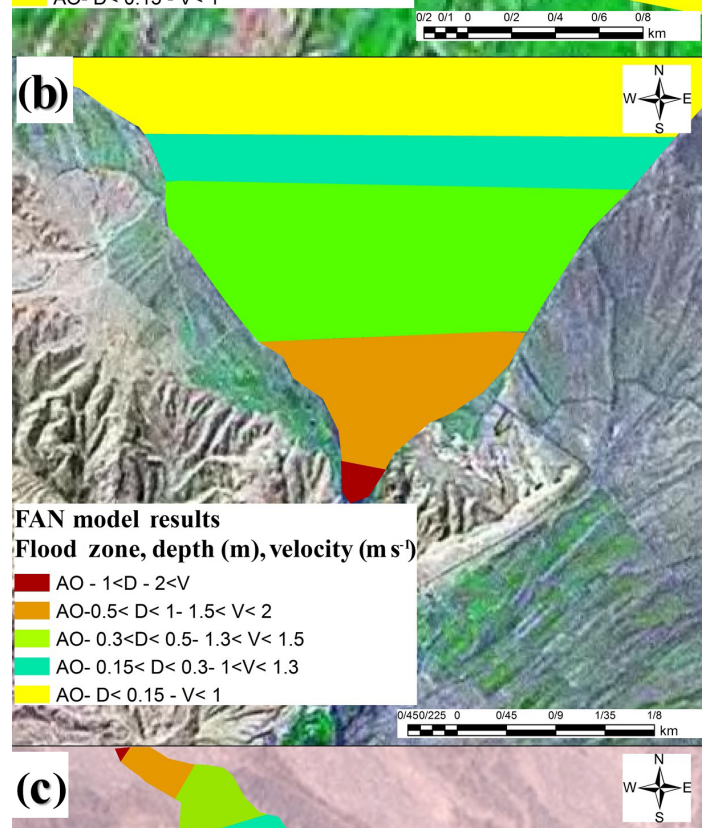

(c)

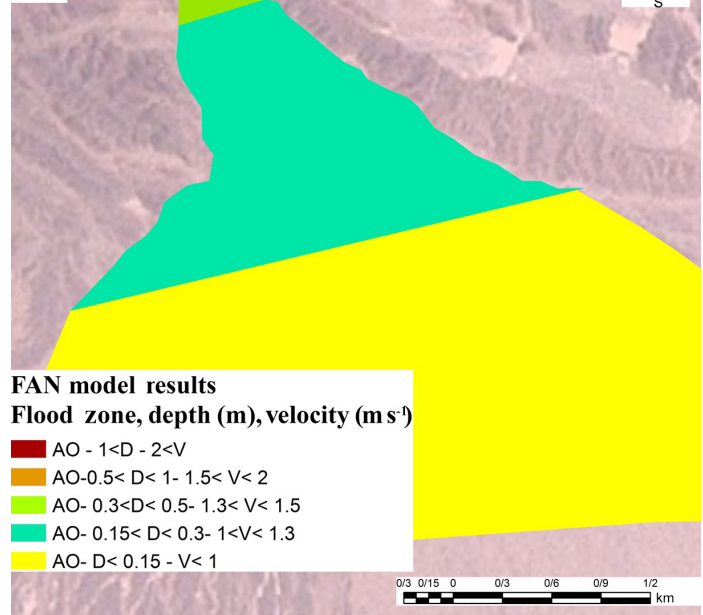

Figure 7. Flood depth and velocity results of the FAN model for the (a) Ardak, (b) Ferizy, and (c) Sarbaz fans.

Figure 6. Aerial images of the (a) Ardak, (b) Ferizy, and (c) Sarbaz fans. 
The Ardak fan is located on the southern piedmont slopes of the Hezarmasjed Mountains, in the Khorasan Province. This alluvial fan is a result of the Ardak river aggradations, and has been subjected to extensive agricultural development due to its fertile soil, which was also followed by residential development (Mollaei et al., 2016a).

The Sarbaz fan is located on the southern piedmont of the Sistan Mountains in Sistan and Baluchestan Province (southeastern Iran). Due to its arid climate, this fan suffers from low average precipitation, high temperatures, low humidity, poor vegetation index, high aggradations, and high volumes of runoff and wind erosion. Sarbaz fan has been formed as a consequence of Sarbaz river aggradations, and unlike Ardak and Ferizy fans, it has not undergone much development. Historic data indicate occurrence of heavy floods and serious destruction in this area, which has been a consequence of flash floods. In the last 60 years over 300 floods occurred in Khorasan, while only 60 floods were recorded in Sistan and Baluchestan Province. According to historic data Khorasan Province has had the highest number of flood occurrence, whereas Sistan and Baluchestan were ranked fifth among all provinces, resulting in USD 19.3 and 33.8 million damage to each province, respectively (Khorsandi et al., 2016).

\section{Results and conclusions}

\subsection{FAN model results}

FAN model output was a text file, which was interpreted in ArcGIS as a shape file for each fan. FAN model results are illustrated in Fig. 7a, b, and c for the Ferizy, Ardak, and Sarbaz fans, respectively. The results are shown in different colors, which correspond to different depths (m) and velocities $\left(\mathrm{m} \mathrm{s}^{-1}\right)$, as explained in Table 3 .

\subsection{FLO-2D model results}

FLO-2D model outputs were a shape file with spatial resolution of $30 \mathrm{~m}$. This model produced three different results of depth $(\mathrm{m})$, velocity $\left(\mathrm{m} \mathrm{s}^{-1}\right)$, and hazard map (low, medium, and high). Its criteria are also explained in Table 3. Figure 8a, b, and c illustrates the depth results of FLO-2D model for the Ferizy, Ardak, and Sarbaz fans, respectively. Also Fig. 9a, b, and c illustrates the velocity results of the FLO-2D model for the mentioned fans.

\subsection{Geomorphological analysis results}

A comparison of the geomorphological characteristics of the three fans showed that while Ardak fan had the greatest area, slope, and discharge, the Ferizy fan had the lowest discharge (Table 3). In Table 4, a comparison of the three fans with regard to their effective characteristics on flood hazards is presented.

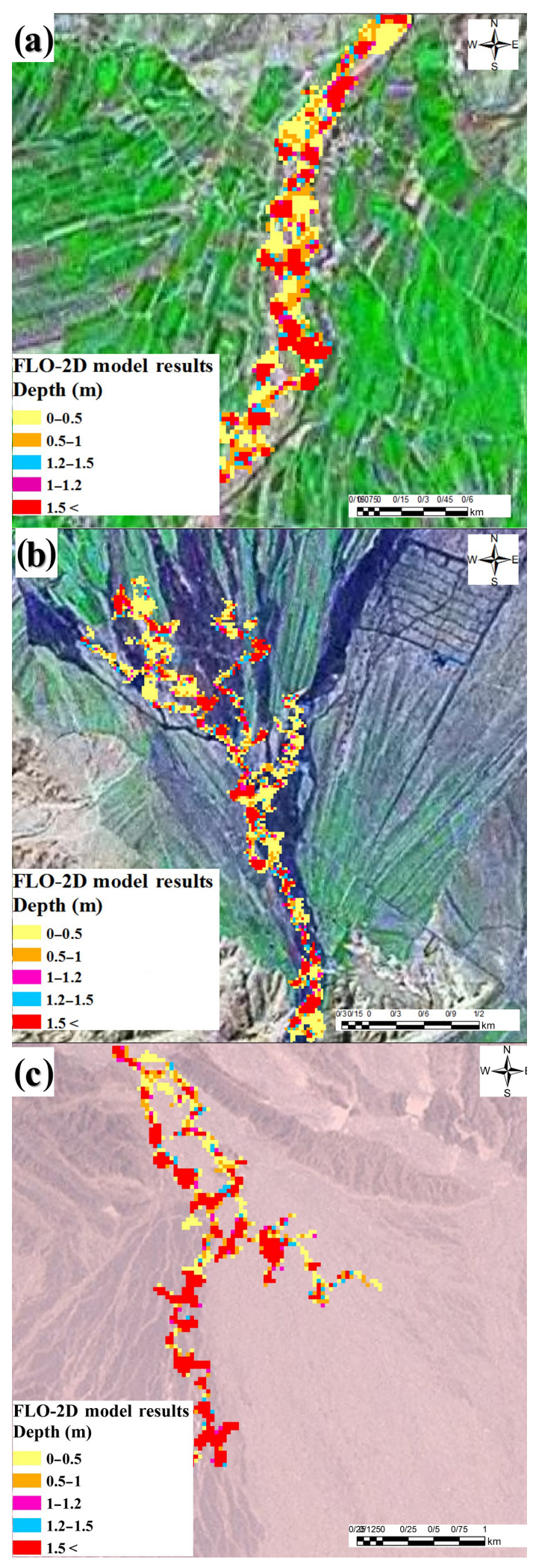

Figure 8. Flood depths results of the FLO-2D model for the (a) Ferizy, (b) Ardak, and (c) Sarbaz fans. 
Table 2. Flood criteria for delineating hazard maps.

\begin{tabular}{|c|c|c|c|c|c|}
\hline \multirow[t]{2}{*}{ Hazard } & \multicolumn{2}{|c|}{ Velocity $\left(\mathrm{m} \mathrm{s}^{-1}\right)$} & \multicolumn{2}{|c|}{ Depth (m) } & \multirow{2}{*}{$\begin{array}{l}\text { Geomorphological } \\
\text { characteristics }\end{array}$} \\
\hline & $\begin{array}{l}\text { FAN } \\
\text { model }\end{array}$ & $\begin{array}{l}\text { FLO-2D } \\
\text { model }\end{array}$ & $\begin{array}{l}\text { FAN } \\
\text { model }\end{array}$ & $\begin{array}{l}\text { FLO-2D } \\
\text { model }\end{array}$ & \\
\hline Very high & $V>2.0$ & $V>1.5$ & $D>1.0$ & $D>1.0$ & active \\
\hline High & $1.5-2$ & $1.2-1.5$ & $0.5-1.0$ & $1.2-1.5$ & active \\
\hline Medium & $1.3-1.5$ & $1.0-1.2$ & $0.3-0.5$ & $1.0-1.2$ & active/inactive \\
\hline Low & $1.0-1.3$ & $0.5-1.0$ & $0.15-0.3$ & $0.5-1.0$ & inactive \\
\hline Very low & $V<1.0$ & $0.0-0.5$ & $D<0.15$ & $0.0-0.5$ & inactive \\
\hline
\end{tabular}

Table 3. The characteristics of three alluvial fans.

\begin{tabular}{|c|c|c|c|}
\hline Sarbaz & Ardak & Ferizy & Characteristic \\
\hline 72 & 497 & 283 & watershed area (apex; $\mathrm{km}^{2}$ ) \\
\hline 70 & 436 & 155 & alluvial fan area $\left(\mathrm{km}^{2}\right)$ \\
\hline 1.03 & 1.83 & 1.04 & average alluvial fan slope (\%) \\
\hline 267.5 & 1284.8 & 1192.7 & average elevation $(\mathrm{m})$ \\
\hline 32 & 17 & 17 & average temperature $\left({ }^{\circ} \mathrm{C}\right)$ \\
\hline 96 & 166 & 167 & average precipitation (mm) \\
\hline $\begin{array}{l}108 \\
\text { concave } \\
\text { channelized } \\
\text { distributary }\end{array}$ & $\begin{array}{l}221.4 \\
\text { concave } \\
\text { channelized } \\
\text { tributary }\end{array}$ & $\begin{array}{l}80.8 \\
\text { concave } \\
\text { channelized } \\
\text { tributary }\end{array}$ & $\begin{array}{l}Q_{100} \text { at apex }\left(\mathrm{m}^{3} \mathrm{~s}^{-1}\right) \\
\text { fan profile shape } \\
\text { drainage pattern }\end{array}$ \\
\hline
\end{tabular}

Table 4. Characteristics of three fans as regarding their flood hazard (velocity, $V$, and depth, $D$, are in $\mathrm{m} \mathrm{s}^{-1}$ and $\mathrm{m}$, respectively).

\begin{tabular}{|c|c|c|c|}
\hline & Ardak & Ferizy & Sarbaz \\
\hline NDVI & 0.115 to 0.71 & -0.157 to 0.768 & -0.161 to 0.427 \\
\hline \multirow{2}{*}{ FLO-2D } & $0<V<1.5$ & $0<V<1.5$ & $0<V<1.5$ \\
\hline & $0<D<1.5$ & $0<D<1.5$ & $0<D<1.5$ \\
\hline \multirow{2}{*}{ FAN } & $0<V<2$ & $0<V<2$ & $0<V<2$ \\
\hline & $0.15<D<1$ & $0.15<D<1$ & $0.15<D<1$ \\
\hline Active/inactive & 0 to 1 & 0 to 1 & 0 to 1 \\
\hline Final score & 0 to 3.195 & 0 to 3.456 & 0 to 1.921 \\
\hline
\end{tabular}

Table 5. Pros and cons of three models and the suggested integrated model.

\begin{tabular}{lllll}
\hline $\begin{array}{l}\text { Models } \\
\text { characteristics }\end{array}$ & FAN & FLO-2D & $\begin{array}{l}\text { Geomorphological } \\
\text { approach }\end{array}$ & $\begin{array}{l}\text { Suggested } \\
\text { integrated } \\
\text { model }\end{array}$ \\
\hline $\begin{array}{l}\text { Depth } \\
\text { Velocity }\end{array}$ & $\sqrt{ }$ & $\sqrt{ }$ & - & $\sqrt{ }$ \\
Active/inactive & - & - & - & $\sqrt{ }$ \\
Fine-resolution results & - & $\sqrt{ }$ & - & $\sqrt{ }$ \\
Required input data & low & high & $\begin{array}{l}\text { low } \\
\text { relatively } \\
\text { complex }\end{array}$ & $\begin{array}{l}\text { low } \\
\text { Degree of simplicity }\end{array}$ \\
\hline simple & complex & simple \\
\hline
\end{tabular}

As can be seen from Table 4, the Sarbaz fan is characterized by high velocity, low channel stability, and low development. The Ardak fan has steep slopes, high peak discharge, and large drainage area. The Ferizy fan does not have any specific characteristics as compared to the Sarbaz and Ardak fans, except for the low channel stability and lower flood 
hazard. The geomorphological map of the Ardak fan shows agricultural and residential activities throughout the fan other than in its main channel. Urbanization of any part of the alluvial fan would create resistance to abrupt changes of flow direction from its main channel, while agricultural lands, especially those with annual crops, would intensify this phenomenon even on the inactive areas of the fan. Obviously, orchards or woodlands are less susceptible to this event as compared to farmlands.

\subsection{Integrated results}

By integrating the results of these three approaches and using the scoring system, each fan was classified into five categories of flood hazard: very high, high, medium, low, and very low. Figure 9a, b, and c show the final flood hazard map for Ferizy, Ardak, and Sarbaz fans, respectively.

As shown in Fig. 10a, b, and c the flood hazard area, apart from their distance from apex of the fan, is also defined based on their distance from riverbanks. In other words, the areas in which the river channels are located, and areas which were previously flood channels, are categorized as high hazard zones.

\subsection{Conclusions}

In this paper, a simple but effective solution to estimate flood hazard is proposed. The presented approach suggests a combination of the FAN model, geomorphological approach and a simple portion of the hydraulic model of FLO-2D.

The FAN model estimates depth and velocity of a flood and requires low input data. However, its results are not accurate for locating the occurrence of depth and velocity of flood in alluvial fans. On the other hand, the FLO-2D model produces accurate depth and velocity results, but, at the same time, it requires too many detailed input data (spatially and temporally) which are costly, time consuming, and cumbersome to collect. It should be emphasized that in many underdeveloped and developing countries, it is impossible to obtain such detailed information due to lack of advanced technology. In addition, FLO-2D is considered to be a complex model which requires a trained operator to work with. With the geomorphological approach, the flood depth and velocity are not determined, and only active and inactive areas could be recognized. The new approach presented in this paper, not only indicates the active and inactive areas, it also accurately estimates the flood depth and velocity, while using the minimum input data; further, it is simple to apply. Table 5 summarizes pros and cons of the FLO-2D, FAN model, the geomorphological approach, and the suggested integrated model.

As illustrated in Table 5, it can be concluded that the integrated method proposed in this study is superior at projecting alluvial fan flood hazards with minimal required input data, simplicity, and affordability, which are considered the primary goals of such comprehensive studies. These advan-

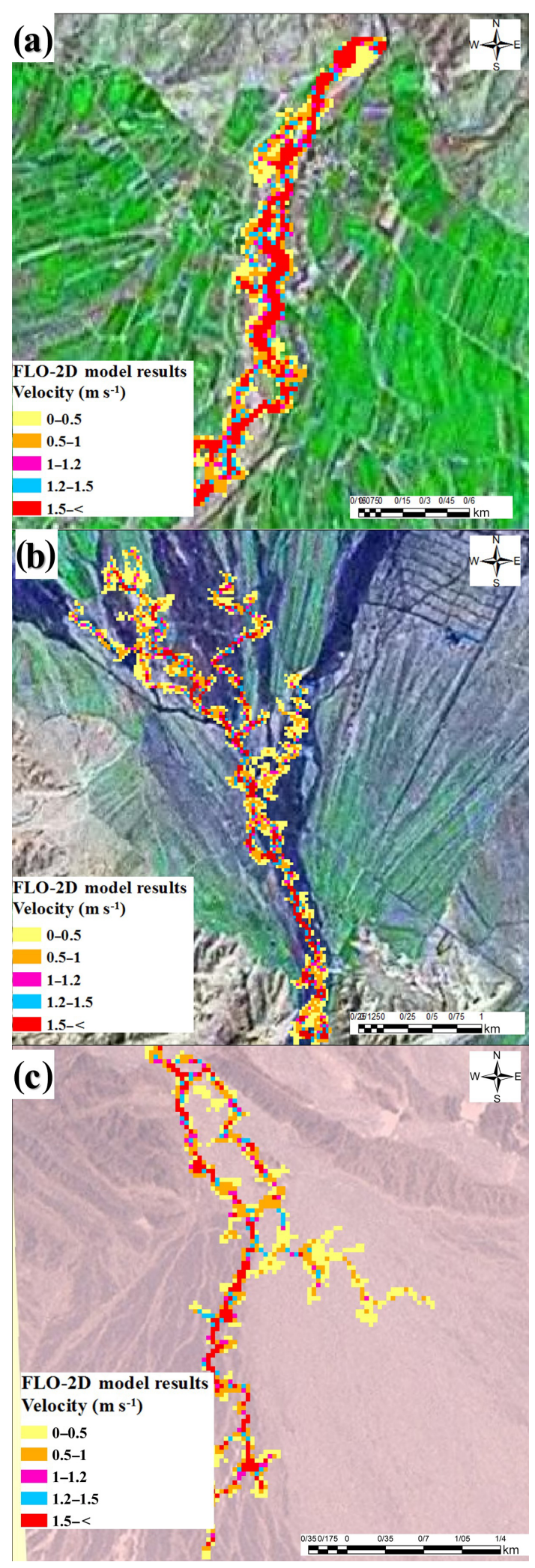

Figure 9. Flood velocities results of the FLO-2D model for the (a) Ferizy, (b) Ardak, and (c) Sarbaz fans. 

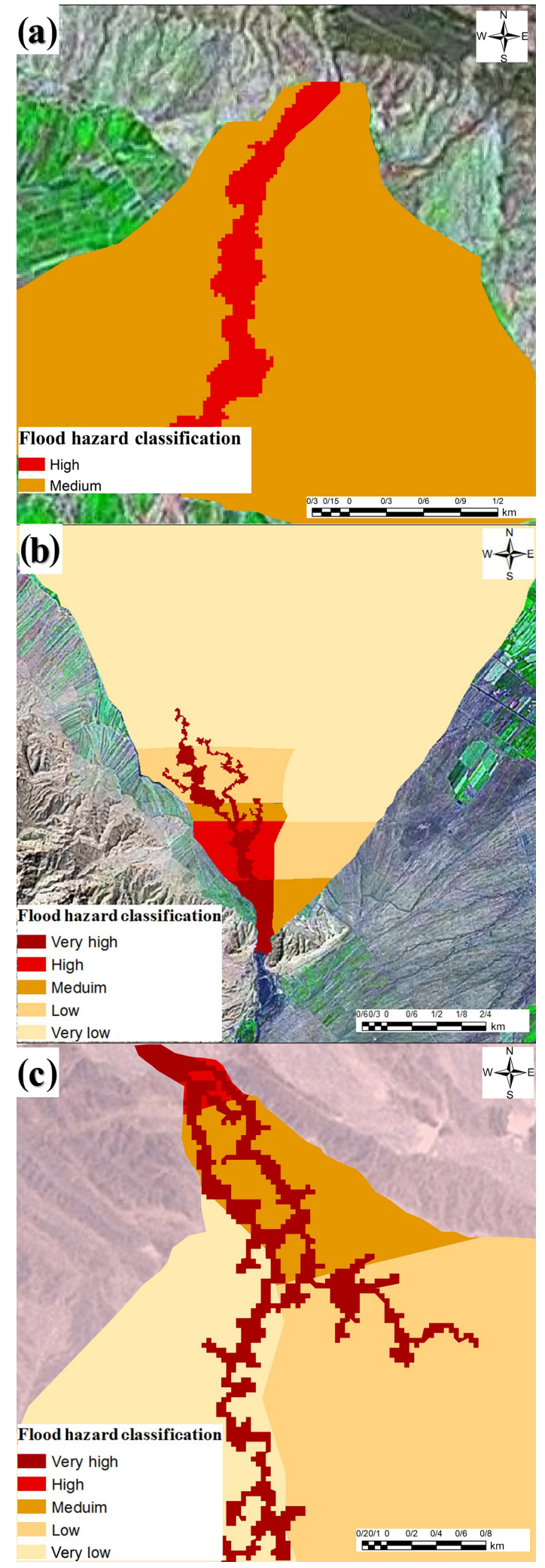

Figure 10. The final integrated results of the FAN model, the FLO2D model and the geomorphological approach for the (a) Ferizy, (b) Ardak, and (c) Sarbaz fans. tages are highlighted for use in underdeveloped and developing countries, which may well lack detailed data and financially cannot support such costly projects. Furthermore, such a highly cost-effective method could be greatly advantageous and pragmatic for developed countries.

For further studies, it is suggested that the HEC-RAS model be used along with the FAN model and geomorphological approach and the results be validated by executing the FLO-2D model utilizing full input data as a reference model.

Data availability. No data sets were used in this article.

Competing interests. The authors declare that they have no conflict of interest.

Edited by: Mario Parise

Reviewed by: three anonymous referees

\section{References}

Bedrossian, T. L., Hayhurst, C. A., Short, W. R., and Lancaster, J. T.: Surficial Geologic Mapping and Associated GIS Databases for Identification of Alluvial Fans, Environ. Eng. Geosci., 20, 335348, https://doi.org/10.2113/gseegeosci.20.4.335, 2014.

Blair, T. C. and McPherson, J. G.: Processes and Forms of Alluvial Fans, in: Geomorphology of Desert Environmen, edited by: Parsons, A. and Abrahams, A., Springer, Boulder City, Colorado, USA, 413-467, 2009.

Calcaterra, D., Parise, M., Palma, B., and Pelella, L.: Multiple debris flows in volcaniclastic materials mantling carbonate slopes, in: Debris-flow hazards Mitig. Mech. Predict. assessment, Balkema, Rotterdam, 99-107, 2000.

Calcaterra, D., Parise, M., and Palma, B.: Combining historical and geological data for the assessment of the landslide hazard: a case study from Campania, Italy, Nat. Hazards Earth Syst. Sci., 3, 3 16, https://doi.org/10.5194/nhess-3-3-2003, 2003.

Coe, J. A., Godt, J. W., Parise, M., and Moscariello, A.: Estimating debris-flow probability using fan stratigraphy, historic records, and drainage-basin morphology, Interstate 70 highway corridor, central Colorado, USA, in: Debris-Flow Hazards Mitigation: Mechanics, Prediction, and Assessment, edited by: Rickenmann, D. and Cheng, C., Proceedings 3rd International DFHM Conference, Davos, Switzerland, 207-217, 2003.

Dawdy, D.: Flood Frequency Estimates on Alluvial Fans, J. Hydraul. Div., 105, 1407-1413, 1979.

DMA Consulting Engineers: Alluvial fan flooding methodology: an analysis for Federal Emergency Management Agency, Marina del Rey, California, 1985.

Elkhrachy, I.: Flash Flood Hazard Mapping Using Satellite Images and GIS Tools: A case study of Najran City, Kingdom of Saudi Arabia (KSA), Egypt. J. Remote Sens. Sp. Sci., 18, 261-278, https://doi.org/10.1016/j.ejrs.2015.06.007, 2015.

Federal Emergency Management Agency: Guidelines and Specifications for Flood Hazard Mapping Partners, in: Vol. 1 Flood 
Stud. Mapp., 1-26, available at: http://www.fema.gov/fhm/dl_ cgs.shtm (last access: April 2018), 2003.

Federal Emergency Management Agency and Federal Insurance Administration: An Alluvial FAN Flooding Computer Program - User Manual, Department of Homeland Security, USA, 1990.

Field, J. J. and Pearthree, P. A.: Geologic Mapping of Flood Hazards' in Arizona: An Example From the White Tank Mountains Area, Maricopa County, Arizona Geological Survey, Tucson, Arizona, USA, 1992.

French, R. H.: Preferred Directions of Flow on Alluvial Fans, J. Hydraul. Eng., 118, 1002-1013, https://doi.org/10.1061/(ASCE)0733-9429(1992)118:7(1002), 1992.

French, R. H., Fuller, J. E., and Waters, S.: Alluvial fan: Proposed New Process-Oriented Definitions for Arid Southwest, J. Water Resour. Pl. Manage., 119, 588-598, 1993.

Fuller, J. E.: Misapplication of the FEMA Alluvial Fan Model: A Case History, Hydraul. Arid Lands, 367-377, 1990.

Fuller, J. E.: Gaps in Fema Guidance for Delineating Flood Hazards on Active Alluvial Fans, J. Flood Eng., 4, 29-38, 2013.

Fuller, J. E.: Floodplain Delineation Study for Richland Ranchettes, http://www.jefuller.com/richland-ranchettes-floodplain-study/ (last access: April 2018), 2010.

Fuller, J. E.: Theoretical And Practical Deficiencies In The Fema Fan Methodology, https://www.researchgate.net/publication/ 265086680_Theoretical_Practical_Deficiencies_in_the_ FEMA_FAN_Model_Theoretical_and_Practical_Deficiencies_ in_the_FEMA_FAN_Methodology (last access: April 2018), 2012.

Gallien, T. W.: Validated coastal flood modeling at Imperial Beach, California: Comparing total water level, empirical and numerical overtopping methodologies, Coast. Eng., 111, 95-104, https://doi.org/10.1016/j.coastaleng.2016.01.014, 2016.

Garfi, G., Bruno, D. E., Calcaterra, D., and Parise, M.: Fan morphodynamics and slope instability in the Mucone River basin (Sila Massif, southern Italy): significance of weathering and role of land use changes, Catena, 69, 181-196, 2007.

Gaume, E., Bain, V., Bernardara, P., Newinger, O., Barbuc, M., Bateman, A., Blaškovičová, L., Blöschl, G., Borga, M., and Dumitrescu, A.: A compilation of data on European flash floods, J. Hydrol., 367, 70-78, 2009.

House, P. K.: Using geology to improve flood hazard management on alluvial fans - An example from Laughlin, Nevada, J. Am. Water Resour. Assoc., 41, 1431-1447, https://doi.org/10.1111/j.1752-1688.2005.tb03810.x, 2005.

House, P. K., Pearthree, P. A., and Vincent, K. R.: Flow patterns, flow hydraulics, and flood-hazard implications of a recent extreme alluvial-fan flood in southern Arizona, Geol. Soc. Am. Abstr. with Programs, 23, A121, 1991.

Kazakis, N., Kougias, I., and Patsialis, T.: Assessment of flood hazard areas at a regional scale using an index-based approach and Analytical Hierarchy Process: Application in RhodopeEvros region, Greece, Sci. Total Environ., 538, 555-563, https://doi.org/10.1016/j.scitotenv.2015.08.055, 2015.

Khorsandi, H., Faghiri, G., and Kalantar, A.: Investigation of Flood Damage, Tehran, https://www.google.com/ url?sa=t\&rct=j\&q=\&esrc=s\&source=web\&cd=1\&ved $=$ 0ahUKEwj-yM7Ox5PaAhVKbK0KHftGBBIQFggpMAA\&url= httpAFFshaghool.irFFilesF164-n.pdf\&usg=
AOvVaw2gMlxKzWcEieon1ReRgdJj (last access: April 2018), 2016.

King, S. G. and Mifflin, E. R.: Alluvial Fan Flooding, in: Inspiration - come to the headwaters: Proceedings of the Fifteenth Annual Conference of the Association of State Floodplain Managers, Natural Hazards Research and Applications Information Center, University of Colorado, Denver, Colorado, p. 243, 1991.

Lancaster, J. T., Spittler, T. E., and Short, W. R.: Using Digital Geologic Maps to Assess Alluvial-Fan Flood Hazards, Sacramento, California, https://pubs.usgs.gov/of/2012/1171/ (last access: April 2018), 2012.

Li, P., Jiang, L., and Feng, Z.: Cross-comparison of vegetation indices derived from landsat-7 enhanced thematic mapper plus (ETM+) and landsat-8 operational land imager (OLI) sensors, Remote Sens., 6, 310-329, https://doi.org/10.3390/rs6010310, 2013.

Lohani, B., Mason, D. C., Scott, T. R., and Sreenivas, B.: Extraction of tidal channel networks from aerial photographs alone and combined with laser altimetry, Int. J. Remote Sens., 27, 5-25, https://doi.org/10.1080/01431160500206692, 2006.

Marchi, L., Cavalli, M., and D'Agostino, V.: Hydrogeomorphic processes and torrent control works on a large alluvial fan in the eastern Italian Alps, Nat. Hazards Earth Syst. Sci., 10, 547-558, https://doi.org/10.5194/nhess-10-547-2010, 2010.

Merheb, M., Moussa, R., Abdallah, C., Colin, F., Perrin, C., and Baghdadi, N.: Hydrological response characteristics of Mediterranean catchments at different time scales: a meta-analysis, Hydrolog. Sci. J., 61, 2520-2539, 2016.

Mollaei, Z., Madani, H., Moghimzadeh, H., Davary, K., and Faridani, F.: Predicting Avulsion Potential On Alluvial Fans Using FLO-2D Model - A Case Study, in: 9th World Congress of EWRA "Water Resources Management in a Changing World: Challenges and Opportunities," EWRA, Istanbul, Turkey, p. 12, 2016a.

Mollaei, Z., Madani, H., Faridhosseini, A., and Davary, K.: Prediction Of Avulsion Phenomenon On Alluvial Fans Using Flo-2d Hydraulic Model, Iran, Water Resour. Res., 11, 172-181, $2016 \mathrm{~b}$.

National Research Council: Alluvial Fan Flooding, National Academies Press, Washington, D.C., 1996.

Nguyen, C. C., Gaume, E., and Payrastre, O.: Regional flood frequency analyses involving extraordinary flood events at ungauged sites: further developments and validations, J. Hydrol., 508, 385-396, 2014.

O'brien, J. S., Julien, P. Y., and Fullerton, W. T.: Twodimensional water flood and mudflow simulation, J. Hydraul. Eng., 119, 244-261, https://doi.org/10.1061/(ASCE)07339429(1993)119:2(244), 1993.

Papaioannou, G., Vasiliades, L., and Loukas, A.: MultiCriteria Analysis Framework for Potential Flood Prone Areas Mapping, Water Resour. Manage., 29, 399-418, https://doi.org/10.1007/s11269-014-0817-6, 2015.

Pearthree, P. A., Demsey, K. A., Onken, J., Vincent, K. R. and House, P. K.: Geomorpidc Assessment of Flood-Prone Areas on the Southern Piedmont of the Tortolita Mountains, Pilvia County, Arizona, Tucson, Arizona, 1992.

Pelletier, J., Mayer, L., Pearthree, P., House, P., Demsey, K., Klawon, J., and Vincent, K.: An integrated approach to flood hazard assessment on alluvial fans using numerical modeling, field map- 
ping, and remote sensing, Geol. Soc. Am. Bull., 117, 1167-1180, https://doi.org/10.1130/B255440.1, 2005.

Santangelo, N., Daunis-i-Estadella, J., Di Crescenzo, G., Di Donato, V., Faillace, P. I., Martín-Fernández, J. A., Romano, P., Santo, A., and Scorpio, V.: Topographic predictors of susceptibility to alluvial fan flooding, Southern Apennines, Earth Surf. Proc. Land., 37, 803-817, 2012.

Santo, A., Santangelo, N., Di Crescenzo, G., Scorpio, V., De Falco, M., and Chirico, G. B.: Flash flood occurrence and magnitude assessment in an alluvial fan context: the October 2011 event in the Southern Apennines, Nat. Hazards, 78, 417-442, 2015.

Vennari, C., Parise, M., Santangelo, N., and Santo, A.: A database on flash flood events in Campania, southern Italy, with an evaluation of their spatial and temporal distribution, Nat. Hazards Earth Syst. Sci., 16, 2485-2500, https://doi.org/10.5194/nhess16-2485-2016, 2016.
Volker, H. X., Wasklewicz, T. A., and Ellis, M. A.: A topographic fingerprint to distinguish alluvial fan formative processes, Geomorphology, 88, 34-45, https://doi.org/10.1016/j.geomorph.2006.10.008, 2007.

Yunsheng, S.: Alluvial Fan Floodplain Mapping East Ojai FLO-2D Floodplain Study, https://www.google.com/url?sa=t\&rct= $\mathrm{j} \& \mathrm{q}=\&$ esrc $=\mathrm{s} \&$ source $=$ web $\& \mathrm{~cd}=1 \&$ ved $=0$ ahUKEwjOs 7Zz5PaAhUPH6wKHTNWDDYQFggpMAA\&url= httpAFFwww.vcfloodinfo.comFpdfFWPD_FLO2D_11_09. pdf\&usg=AOvVaw35kXyCyI9R86A2p-pHbhwc (last access: April 2018), 2009.

Zanter, K.: LANDSAT 8 (L8) Data Users Handbook, http://ktisis. cut.ac.cy/bitstream/10488/9090/1/GeorgiouandSkarlatos.pdf (last access: April 2018), 2016.

Zhao, B. and Mays, L. W.: Alluvial-Fan Method, J. Hydraul. Eng., 122, 325-332, 1996. 